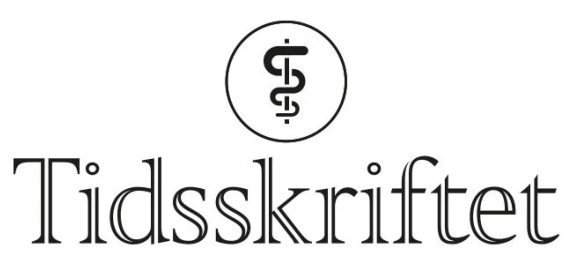

DEN NORSKE LEGEFORENING

\title{
Brunt serum
}

\author{
MEDISINEN I BILDER
}

HELLE BORGSTRØM HAGER

helle.hager@siv.no

Sentrallaboratoriet

Sykehuset i Vestfold

Helle Borgstrøm Hager er spesialist i medisinsk biokjemi og avdelingsoverlege.

Forfatteren har fylt ut ICMJE-skjemaet og oppgir ingen interessekonflikter.

\section{MAGNUS MOKSNES}

Seksjon for blodsykdommer

Medisinsk avdeling

Sykehuset i Vestfold

Magnus Moksnes er overlege.

Forfatteren har fylt ut ICMJE-skjemaet og oppgir ingen interessekonflikter.

\section{METTE BROKNER}

Sentrallaboratoriet

Sykehuset i Vestfold

Mette Brokner er spesialist i medisinsk biokjemi og overlege.

Forfatteren har fylt ut ICMJE-skjemaet og oppgir ingen interessekonflikter. 


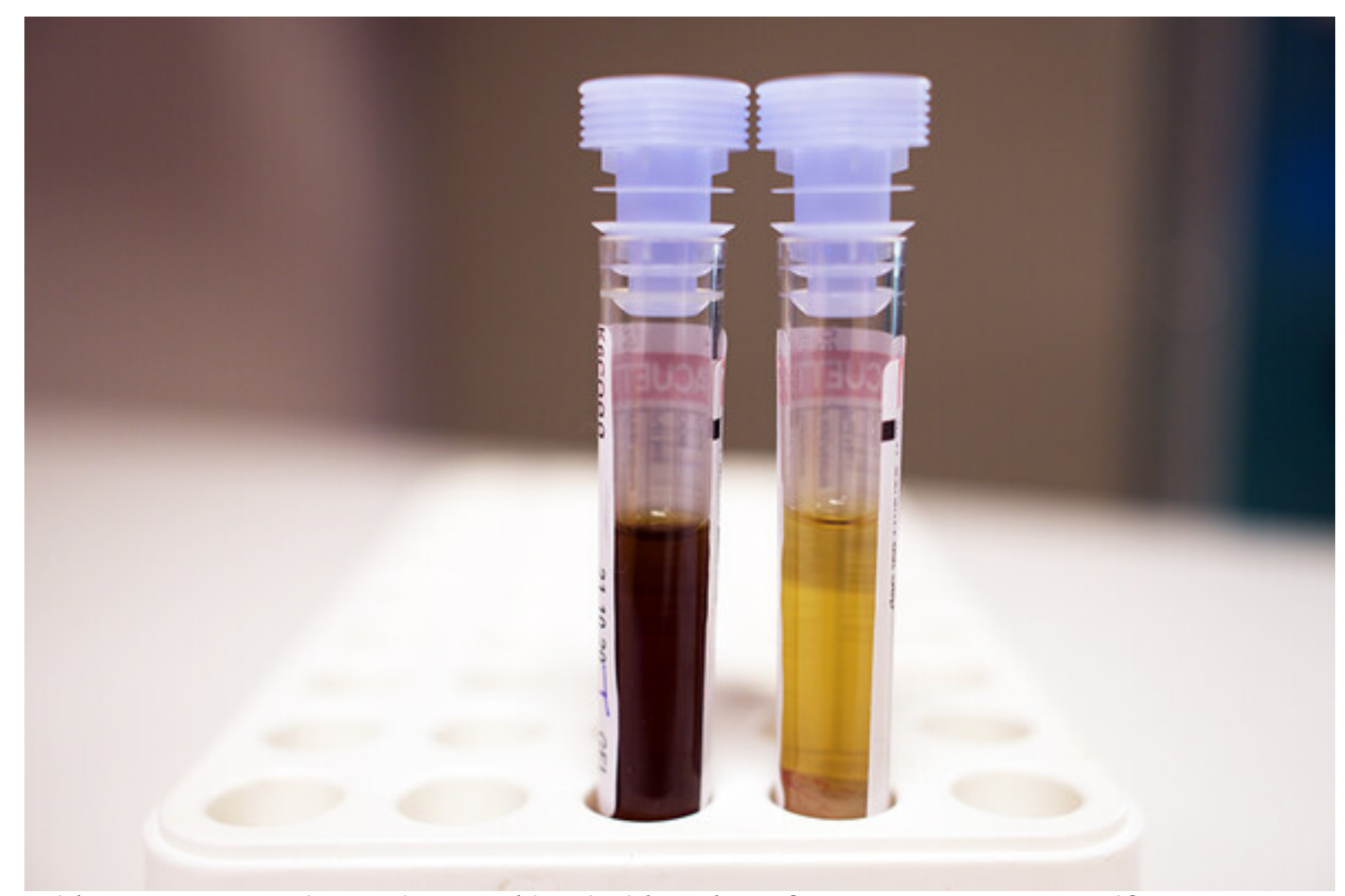

Bildet viser prøvetakingsglass med henholdsvis brunfarget serum og normalfarget serum. Den brunfargede prøven er fra en mann i zo-årene som var innlagt med infeksjon og transplantatsvikt etter allogen stamcelletransplantasjon for akutt myelogen leukemi.

Brunfarget serum skyldes vanligvis alvorlige tilstander som massiv intravasal hemolyse eller methemoglobinemi. Ved intravasal hemolyse vil hemoglobin fra erytrocyttene frigjøres og bindes i sirkulasjonen til haptoglobin. Det dannes hemoglobinhaptoglobinkomplekser som raskt elimineres av monocytter og makrofager, og haptoglobinkonsentrasjonen faller til ikke-målbare nivåer. Ved mer omfattende hemolyse vil haptoglobinets bindingskapasitet overskrides. Jernet i hemoglobin oksideres, og det dannes methemoglobin. Methem avspaltes og bindes til albumin (methemalbumin) og hemopeksin for videre transport til lever og nedbrytning til bilirubin. Methemalbumin og hemopeksinhem gir serum en skittenbrun farge.

Methemoglobinemi kan også skyldes oksiderende legemidler (for eksempel dapson og noen antimalariamidler) eller toksiner, og kan en sjelden gang være medfødt. Blod som inneholder over 10-15\% methemoglobin, får en sjokoladelignende farge (1).

Methemoglobin hos pasienten ble målt til 5 \% (referanseområde <2), mens haptoglobin var $2,44 \mathrm{~g} / \mathrm{L}(0,40-1,90)$ og bilirubin $17 \mu \mathrm{mol} / \mathrm{L}(<25)$. Pasienten brukte dapson som profylakse mot pneumocystispneumoni. Dette kunne forklare lett methemoglobinemi, men ikke den mørkebrune serumfargen.

Pasientens serum forble brunt etter seponering av dapson. Han var også under behandling med eltrombopag (150 mg daglig), en trombopoietinreseptoragonist som kan gis ved alvorlig aplastisk anemi og immunologisk trombocytopeni. Medikamentet har en sterk egenfarge og gir i høye doser misfarging av serum, og det kan også gi ikterusliknende farge på hud og sklera (2). Det er nyttig for klinikere og laboratorieansatte å kjenne til at behandling med eltrombopag i høye doser kan medføre brunfarget serum. Brunfargen kan også medføre analytisk interferens ved enkelte spektrofotometriske analysemetoder.

Pasienten har gitt samtykke til at artikkelen blir publisert. Artikkelen er fagfellevurdert.

\section{LITTERATUR}

1. Solheim L, Brun AC, Greibrokk TS et al. Methemoglobinemia-causes, diagnosis and treatment. Tidsskr Nor Lægeforen 2000; 120: 1549-51. [PubMed] 
2. Rodgers GM, Kurtti AL, Gilreath JA. Are eltrombopag plasma and skin hyperpigmentation related? The eyes have it. Am J Hematol 2019; 94:394-5. [PubMed][CrossRef]

Publisert: 25. oktober 2021. Tidsskr Nor Legeforen. DOI: 10.4045/tidsskr.21.0418

Mottatt 18.5.2021, første revisjon innsendt 17.8.2021, godkjent 27.8.2021.

(C) Tidsskrift for Den norske legeforening 2023. Lastet ned fra tidsskriftet.no 26. april 2023. 